\title{
Grazing Management of Crested Wheat- grass Range for Yearling Steers
}

\author{
D.A. DAUGHERTY, C.M. BRITTON, AND H.A. TURNER
}

\begin{abstract}
Sixty, spring-born, yearling steers of Angus-Hereford breeding were used to compare continuous vs short duration grazing on crested wheatgrass range. Grazing trials were conducted in two successive years. Grazing fields to remove about $30 \%$ of available forage and then moving to a fresh field increased $(P<.05)$ daily gains of steers compared to continuous grazing. However, this increase occurred late in the grazing season with no apparent initial advantage for short duration grazing. The effect of grazing treatments on forage yields and quality resulted in several management implications. These implications and further research needs are discussed.
\end{abstract}

A successful grazing management plan should consider seasonal quality of forage resources, adapt them to animal requirements and maximize animal production without adversely affecting longterm forage production. Van Poollen and Lacey (1979) reviewed specialized grazing systems on western ranges and concluded that they increased mean annual forage production by $13 \%$ compared to continuous or season-long grazing. Reducing stocking levels had an even greater effect. Additionally, Allison and Kothmann (1979) found that with lower stocking levels animals selected higher quality diets.

Crested wheatgrass on ranges of eastern Oregon has a growing season of April, May, and June. Forage is of high nutritive value early in the season but decreases rapidly in digestible protein and energy with increasing maturity. Young rapidly growing animals can efficiently utilize early season high quality forage and yearling steers can maintain daily gains above $0.8 \mathrm{~kg}$ through mid-June (Raleigh 1970). After this time, gains decrease with decreasing forage quality.

Crested wheatgrass develops stiff unpalatable culms and a high stem to leaf ratio with increasing maturity. However, Hyder and Sneva (1963) have shown that adjusting stocking levels to achieve close grazing in late May, while plants are in the boot stage, will reduce formation of reproductive shoots and stimulate vegetative growth.

The objectives of the current trials were to evaluate short duration and continuous grazing schemes. Results were compared by measurement of yearling steer gains and changes in quantity and quality of the forage resource.

\section{Study Area and Methods}

The study area consisted of two crested wheatgrass (Agropyron desertorum) ranges located at the Squaw Butte Experimental Range Ranch approximately $60 \mathrm{~km}$ west of Burns, Ore. The ranges consisted of 29 and 62 ha with the larger site divided into five fields

At the time of research, the authors were, respectively, graduate research assistant. and associate professors, Oregon Agricultural Experiment Station, Burns, Oregon 97720. D.A. Daugherty is now a nutrition consultant with Loper Systems, Corona. Calif. 91720 and C.M. Britton is with Texas Tech University, Lubbock 79409.

This research involved in a cooperative effort of Eastern Oregon Agr. Res. and U.S. Dep. Agr., Agr. Res. Serv., Burns, Ore. and was partially supported by Cooperative State Res. Serv., U.S. Dep. Agr., Washington D.C. 20250.

Technical Paper No. 5559. Oregon Agr. Exp. Sta.

Manuscript received August 26, 1980. of 6.5 to 28 ha in size. Both ranges have approximately equal production capabilities based on past use records. Mean elevation is $1375 \mathrm{~m}$ and a nnual precipitation is $30 \mathrm{~cm}$. About $70 \%$ occurs as snow in winter and the remainder as rain during the growing season.

Thirty, spring-born, yearling steers of Angus-Hereford breeding were used as study animals in each of two trials during the spring and summers of 1978 (Trial 1) and 1979 (Trial 2). Mean initial steer weights were 281 and $260 \mathrm{~kg}$ for Trials 1 , and 2, respectively. Steers were randomly assigned to grazing treatments by weight and previous winter treatment, which consisted of two levels of energy supplementation.

Experimental treatments consisted of two grazing practices on crested wheatgrass range to determine effects on performance of yearling steers and to determine the effects of grazing on forage yields and quality. Continuous (C) season-long grazing on a 29-ha range was compared with a specialized grazing treatment, designated as short-duration grazing, on pastures of a 62-ha range.

Short-duration grazing (S) was designed to utilize $30 \%$ of available forage at the time steers were placed in the field and then moved to an ungrazed field. Steer movements were based on hand clipping estimates of forage yield and estimated consumption of steers. Forage available for grazing was estimated as $80 \%$ of the total and consumption of steers was estimated using $2.75 \%$ of their body weight. The five fields on the $S$ treatment were $9,9,6.5,9$, and 28 ha in size and were grazed in the order listed with the largest field last to insure sufficient forage for completion of the trials.

Steers started treatment during both trials in early May as forage yield reached $225 \mathrm{~kg} /$ ha as recommended by Sharp (1970). A daily supplement schedule of barley and biuret developed at Squaw Butte Experimental Station (Table 1) was fed from June 15 to August 15 to insure gains of $.85 \mathrm{~kg}$ or better (Raleigh 1970). Initial and final steer weights were taken in Trial 1 with additional weights at 28 -day intervals in Trial 2 . The trials were terminated by August 15 of both years as higher levels of supplement are necessary to account for the decreasing forage quality and resultant reduced intake of forage.

Forage yields in both trials were estimated by hand clipping 20 , $1-\mathrm{m}^{2}$ circular quadrats in each $\mathrm{S}$ treatment field before and after grazing and in the $\mathrm{C}$ treatment field at monthly intervals. Forage samples were dried in a forced-air oven $\left(60^{\circ} \mathrm{C}\right)$ for 48 hours, weighed to the nearest $1 \mathrm{~g}$ and reported as $\mathrm{kg} /$ ha. Forage was composited into two samples for each field by clipping date, ground through a Wiley mill, subsampled, and analyzed for Kjeldahl-N. Nitrogen concentrations were reported as crude protein.

Animal performance data were subjected to least squares analysis of variance and differences in treatment means determined by using Student's $t$ test at $P<.05$ (Steel and Torrie 1960). Polynomial curve fitting was used to describe response curves for forage yields, crude protein percents and yields, and animal growth rates across time (Snedecor and Cochran 1972). Forage curves represent the period of March 15 (day 1) through September 15 (day 180) and animal curves represent the period of May 5 (day 50) through August 15 (day 150). 
Table 1. Daily supplement schedule for yearling steers grazing crested wheatgrass range (Trials 1 and 2).

\begin{tabular}{lcc}
\hline \hline Period & $\begin{array}{c}\text { Nitrogen } \\
(\mathrm{g})\end{array}$ & $\begin{array}{c}\text { Digestible energy' } \\
\text { (kcal) }\end{array}$ \\
\hline Start-6/15 & 7.8 & 1640 \\
$6 / 16-6 / 17$ & 13.2 & 1640 \\
$6 / 18-6 / 19$ & 15.0 & 1640 \\
$6 / 20-6 / 25$ & 16.9 & 1640 \\
$6 / 26-7 / 2$ & 24.1 & 1640 \\
$7 / 3-7 / 9$ & 28.3 & 2133 \\
$7 / 10-7 / 16$ & 34.3 & 2625 \\
$7 / 17-7 / 23$ & 39.5 & 2954 \\
$7 / 24-8 / 4$ & 44.9 & 4100 \\
$8 / 5-$ end & 48.8 & 4920 \\
\hline
\end{tabular}

'Biuret and barley were used as supplemental sources of nitrogen and digestible energy, respectively. While supplemental nitrogen was not considered necessary until $6 / 16$, the barley supplied small amounts as indicated.

\section{Results}

Polynomial equations for the response across time of forage yield between years and treatments and the effects of grazing on forage yield, crude protein content, and crude protein yield are presented in tabular form (Table 2) to support the subsequent discussion of response curves. Variation in precipitation patterns

Table 2. Polynomial equations for forage yield and quality responses across time.

\begin{tabular}{|c|c|c|}
\hline Equation' & $R^{2}$ & $P$ value \\
\hline $\begin{array}{l}\text { Forage yield }(\mathrm{kg} / \mathrm{ha}) \\
\qquad \begin{array}{l}1978 \mathrm{Y}=180.405-17.3378 \mathrm{x}+.6781 \mathrm{x}^{2}-.0048 \mathrm{x}^{3} \\
\quad+.0000097 \mathrm{x}^{4} \\
1979 \mathrm{Y}=182.214-15.1156 \mathrm{x}+.4806 \mathrm{x}^{2}-.00236 \mathrm{x}^{3}\end{array}\end{array}$ & .99 & $\begin{array}{l}<.001 \\
<.001\end{array}$ \\
\hline $\begin{array}{l}\text { Range site yield } 2(\mathrm{~kg} / \mathrm{ha}) \\
\text { C Y }=-1247.052+37.633 \mathrm{x}-.17084 \mathrm{x}^{2} \\
\mathrm{~S} \mathrm{Y}=-1125.208+36.645 \mathrm{x}-.16718 \mathrm{x}^{2}\end{array}$ & $\begin{array}{l}.93 \\
.99\end{array}$ & $<.001$ \\
\hline Forage yield ${ }^{3}$, ungrazed $(\mathrm{U})$ vs grazed $(\mathrm{G}),(\mathrm{kg} / \mathrm{ha})$ & & \\
\hline $\begin{array}{l}1978 \text { (U) } Y=94.348-8.112 x+.40893 x^{2}-.00188 x^{3} \\
\text { (G) } Y=-785.004+32.031 x-.1879 x^{2} \\
-.00044 x^{3} \\
1979 \text { (U) } Y-182.203-15.114 x+.4806 x^{2} \\
-.00236 x^{3} \\
\text { (G) } Y=-6917.72+241.326 x-2.484 x^{2}+ \\
.08811 x^{3}\end{array}$ & $\begin{array}{l}.97 \\
.99\end{array}$ & $\begin{array}{r}<.001 \\
<.001 \\
<.001 \\
\\
\quad .06\end{array}$ \\
\hline $\begin{array}{l}\text { Crude protein }(\%) \\
\text { (U) } Y=23.4288-.2585 x+.00083 x^{2} \\
\text { (G) } Y=24.6898-.2973 x-.00103 x^{2}\end{array}$ & $\begin{array}{l}.97 \\
.99\end{array}$ & $\begin{array}{l}<.001 \\
<.001\end{array}$ \\
\hline $\begin{array}{l}\text { Crude protein yield }(\mathrm{kg} / \mathrm{ha}) \\
\text { (U) } \mathrm{Y}=-35.1951+2.3516 \mathrm{x}-.01237 \mathrm{x}^{2} \\
\text { (G) } \mathrm{Y}=-358.428+14.0119 \times .15044 \mathrm{x}^{2} .00496 \mathrm{x}^{3}\end{array}$ & $\begin{array}{l}.67 \\
.97\end{array}$ & $\begin{array}{l}.11 \\
.02\end{array}$ \\
\hline
\end{tabular}

$\mathrm{I}_{\mathrm{x}}=$ days with day 1 bcing March 15.

2Continuous and short duration grazing represented by $\mathrm{C}$ and $\mathrm{S}$, respectively.

'Ungrazed and grazed represented by $U$ and $G$, respectively.

between the 2 years of study resulted in considerable differences in forage production (Fig. 1). Precipitation for 1978 and 1979 totaled 28.0 and $32.0 \mathrm{~cm}$, respectively, was similar to the 30 year average of $29.7 \mathrm{~cm}$. However, in 1978, March, April, and May precipitation totaled $4.4 \mathrm{~cm}$ compared to $2.1 \mathrm{~cm}$ for 1979 and $3.0 \mathrm{~cm}$ for the 30-year average. This additional moisture in 1978 lengthened the growing season and resulted in $130 \%$ of the long-term average forage production compared to 1979 which represents $90 \%$ of the average forage year (Sneva 1979, unpublished data).

The $\mathrm{S}$ treatment was designed to graze $30 \%$ of the forage available at the time steers were moved onto a field. Pasture size, days grazed and percent utilization are presented in Table 3. Grazing at

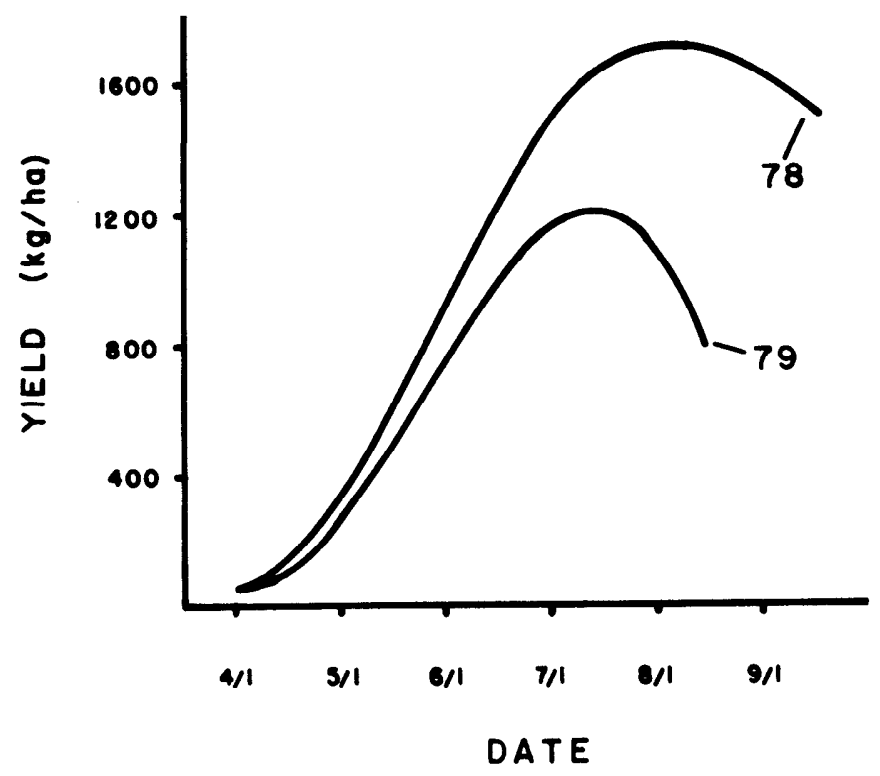

Fig. 1. Crested wheatgrass yields ( $\mathrm{kg} / \mathrm{ha}$ ) on ungrazed plots for 1978 (Trial l) and 1979 (Trial 2).

Table 3. Pasture size, days grazed, and percent utilization for pastures on the short duration (S) treatment.

\begin{tabular}{lccccc}
\hline & \multicolumn{2}{c}{1978} & & \multicolumn{2}{c}{1979} \\
\cline { 2 - 3 } \cline { 5 - 6 } Pasture size & Days grazed & $\begin{array}{c}\text { Utilization } \\
(\%)\end{array}$ & & Days grazed & $\begin{array}{c}\text { Utilization } \\
(\%)\end{array}$ \\
\hline (ha) & & & & \\
9.1 & 7 & 24.1 & & 26.8 \\
9.1 & 10 & 21.4 & & 12 & 27.5 \\
6.5 & 11 & 24.9 & & 11 & 27.0 \\
9.3 & 14 & 24.1 & & 17 & 25.8 \\
27.9 & 6 & 22.8 & & 49 & 19.5 \\
\hline
\end{tabular}

this level had little effect on forage growth rates early in the growing season. This is illustrated by differences between yicld estimates made on ungrazed fields (U) and yield estimates made after grazing (G) in Trial 1 (Fig. 2) and Trial 2 (Fig. 3). Differences

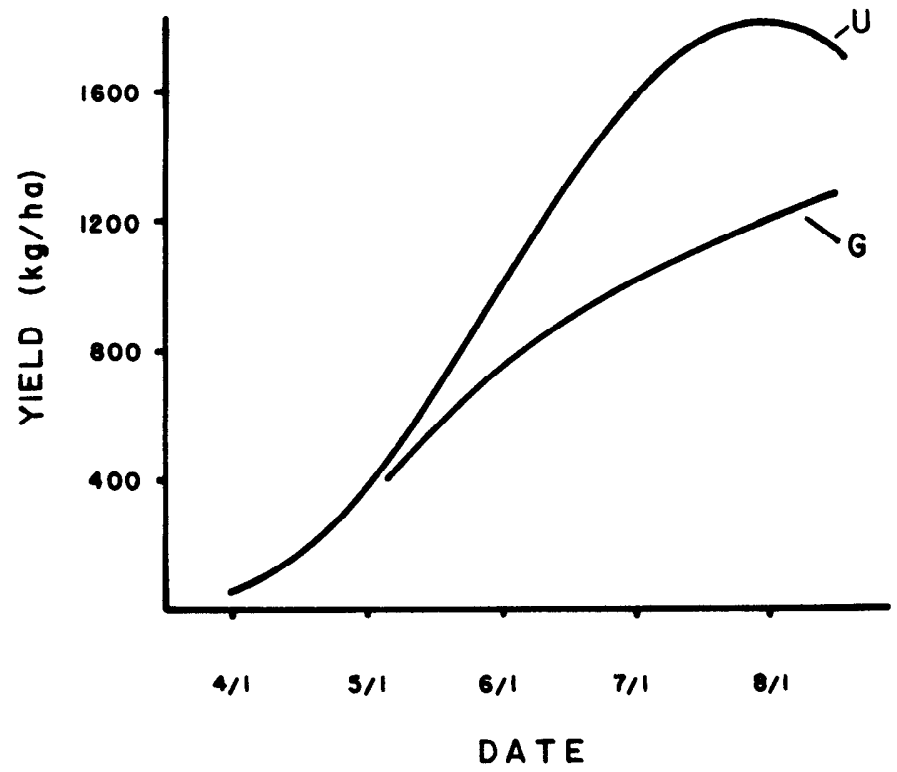

Fig. 2. Crested wheatgrass yield $(\mathrm{kg} / \mathrm{ha}$ ) before $(U)$ and after $(G)$ grazing on the short duration treatment site for 1978 (Trial 1). 


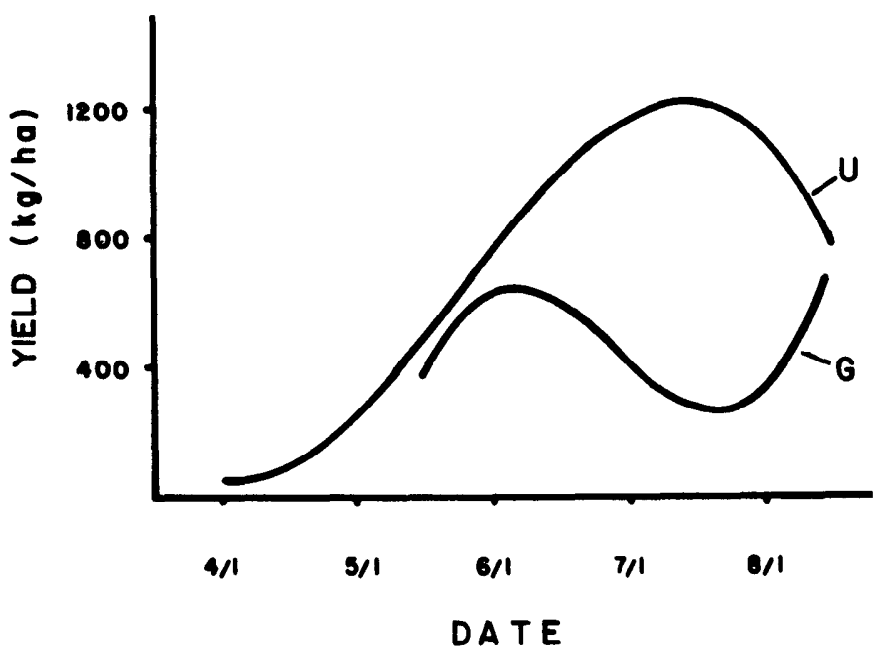

Fig. 3. Crested wheatgrass yield $(\mathrm{kg} / \mathrm{ha})$ before $(U)$ and after $(G)$ grazing on the short duration treatment site for 1979 (Trial 2).

in yield were accounted for by estimated steer consumption. However, as moisture became limiting and forage growth rates slowed, the yield difference between $U$ and $G$ increased. This response came later in Trial 1 due to the above average spring precipitation. As moisture became limiting, grazing reducing forage growth rates and this effect was greater during the drier year of 1979. Trampling and increased leaf shatter from grazing after forage matured also had a role in increasing the difference between $U$ and $G$ forage yields.

Forage yields increased on the grazed ranges in August for Trial 2 (Fig. 3). This upswing in forage yields was a result of regrowth from early August precipitation levels 3-fold greater than average. Regrowth was substantially greater on grazed as compared to ungrazed areas.

Grazing decreased the crude protein content of forage compared to ungrazed forage on the $S$ teatment for Trials 1 and 2 combined (Fig. 4). Steers were able to select for the higher quality forage parts (leaves) throughout the grazing season. Combined crude protein yields (Fig. 5) before and after grazing for Trials 1 and 2 were largely a function of forage yields and have similar response curves. The increasing difference between grazed and ungrazed forage for crude protein yields after maturity was probably the result of both increased leaf shatter from grazing and the selectivity by animals for the higher quality forage parts. Regrowth in August of 1979

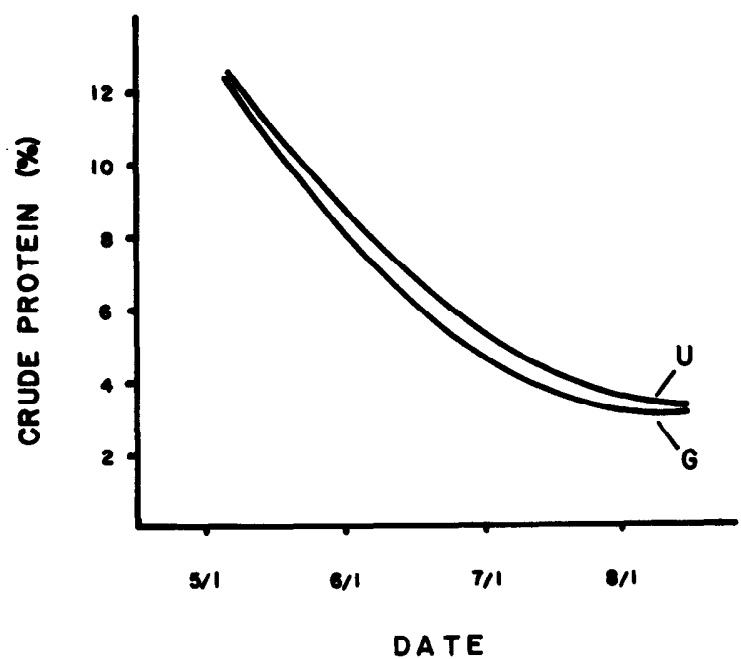

Fig. 4. Crude protein content $(\%)$ of crested wheatgrass before $(U)$ and after $(G)$ grazing on the short duration treatment site for Trials 1 and 2 combined.

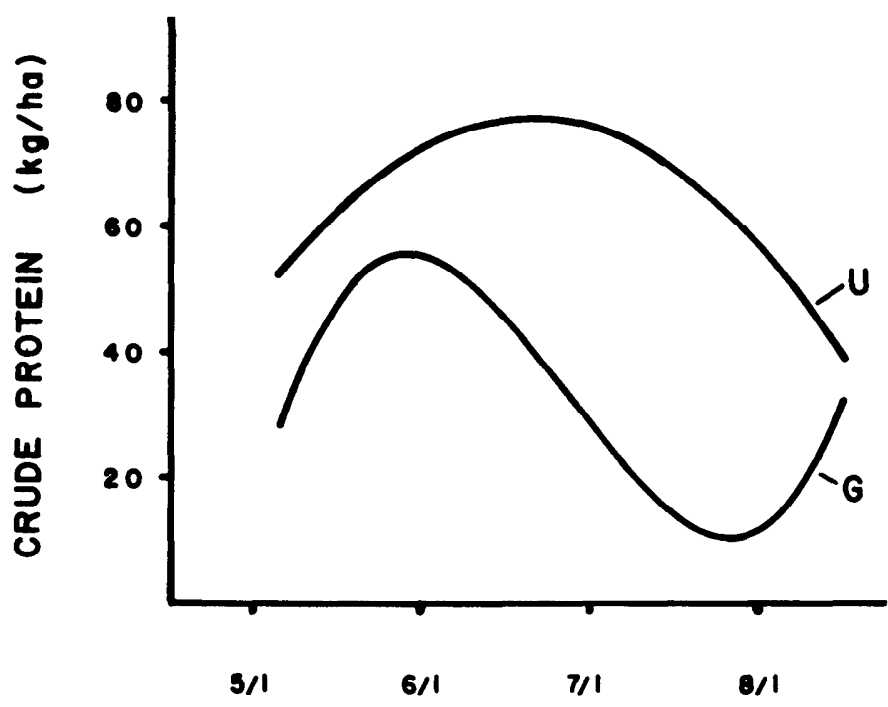

D A TE

Fig. 5. Crude protein yield ( $\mathrm{kg} / \mathrm{ha}$ ) of crested wheatgrass before $(U)$ and after $(G)$ grazing on the short duration treatment site for Trials 1 and 2 combined.

resulted in a large increase in crude protein yield with the greater response occurring on grazed forage.

The $\mathrm{S}$ treatment produced significantly higher animal daily gains $(P<.05)$ than the $C$ treatment. Animal weights were greater on the $S$ treatment than the $C$ treatment but not significantly so because of the length of the trials (Table 4). Steers had greater daily gains on the $\mathbf{S}$ treatment regardless of the previous low or high energy winter treatment. However, steers from the previous low energy winter treatment made compensatory gains during the grazing season, which reduced the magnitude of the effects of the grazing treatments.

Table 4. The effects of grazing treatment on yearling steer performance.

\begin{tabular}{|c|c|c|c|c|}
\hline \multirow[b]{2}{*}{ Item } & \multicolumn{2}{|c|}{ Trial 1} & \multicolumn{2}{|c|}{ Trial 2} \\
\hline & Continuous & Short duration & Continuous & Short duration \\
\hline No. of steer & 15 & 15 & 15 & 13 \\
\hline $\begin{array}{l}\text { Grazing period, } \\
\text { days }\end{array}$ & 105 & 105 & 97 & 97 \\
\hline Initial wt, kg & $281.8 \pm 33.8$ & $280.4 \pm 30.3$ & $259.1 \pm 26.4$ & $260.9 \pm 22.9$ \\
\hline Final wt, $\mathrm{kg}$ & $376.5 \pm 33.0$ & $386.2 \pm 31.9$ & $364.3 \pm 27.8$ & $373.7 \pm 18.4$ \\
\hline Gain, kg' & $94.7 \pm 19.5 \mathrm{a}$ & a $105.7 \pm 11.3 \mathrm{~b}$ & $105.2 \pm 8.8 \mathrm{a}$ & $112.8 \pm 7.7 \mathrm{~b}$ \\
\hline Daily gain. $\mathrm{kg}$ & $.90 \pm .19 \mathrm{a}$ & $1.01 \pm .11 \mathrm{~b}$ & $1.08 \pm .09 \mathrm{a}$ & $1.16 \pm .08 \mathrm{~b}$ \\
\hline
\end{tabular}

ITwo steers died of unknown causes on the short duration grazing treat ment in trial 2. ${ }^{2}$ Means within trials followed by different letters differ significantly $(P<.05)$.

Additional steer weights at monthly intervals in Trial 2 and formulation of polynomial equations for rate of gain and steer weights across time (Table 5) allowed for better interpretation of the effects of the two grazing treatments on animal performance. The $\mathrm{S}$ treatment had no beneficial effect on steer performance early in the grazing season as the steers on the $C$ treatment also had access to an abundance of high quality forage. Daily gains were less $(P<.05)$ on the $S$ treatment compared to the $C$ treatment during May and June (Fig. 6). However, as forage matured, the increased selectivity by steers on the $\mathrm{S}$ treatment resulted in significantly greater daily gains for the remainder of the grazing period. The $S$ treat ment produced heavier steers by the end of the grazing periods (Fig. 7).

\section{Discussion}

The results of these trials provide several management implications for crested wheatgrass range. Crested wheatgrass is charac- 
Table 5. Polynomial equations for steer rate of gain and weight responses across time.

\begin{tabular}{lll}
\hline \hline Equation' & $R^{2}$ & $P$ value \\
\hline Steer weight ${ }^{2},(\mathrm{~kg})$ & & \\
C Y $=179.748+1.6139 \mathrm{x}-.00245 \mathrm{x}^{2}$ & .99 & $<.001$ \\
$\mathrm{~S} \mathrm{Y}=219.197+.4944 \mathrm{x}+.00376 \mathrm{x}^{2}$ & .99 & $<.001$ \\
& & \\
Rate of gain, $(\mathrm{kg} /$ day) & .99 & $<.001$ \\
C Y $=-2.006+.06097 \mathrm{x}-.00028 \mathrm{x}^{2}$ & .87 & $<.001$ \\
S Y $=-1.528+.04545 \mathrm{x}-.00018 \mathrm{x}^{2}$ & & \\
\hline
\end{tabular}

${ }^{1} \mathrm{x}=$ days starting with day 50 being May 5 .

${ }^{2}$ Continuous and short duration grazing represented by $\mathrm{C}$ and $\mathrm{S}$, respectively.

terized by vegetative shoots which arise from axillary buds of old stem bases. Differentiation of some shoot apices to reproductive shoots occurs in early May and is followed by rapid elongation of the shoot apex. Hyder and Sneva (1963) concluded that stocking to achieve close grazing about May 20 to 25 while the heads are in the boot stage will stimulate tillering of new vegetative shoots. This is dependent upon removal of the shoot below the rudimentary inflorescence, otherwise the reproductive shoots will continue to grow with no further leaf development.

The $\mathrm{S}$ treatment of the current studies was designed to achieve maximal animal gain from the early-season, high-quality forage with little regard for its affects on total forage production. Removal of $30 \%$ of the forage from fields early in the season would not be sufficient to stimulate tillering. Therefore, it would be critical to the grazing management plan to follow the $S$ treatment steers with other animals to achieve close grazing in late May to early June. Added advantages are maximizing nutrient harvest, limiting dry matter loss from leaf shatter, and increasing regrowth potential.

Although the $\mathrm{S}$ treatment resulted in a significant increase in overall daily gains, the daily gains were lower early in the grazing season. No difference was expected between gains early in the season as steers on both the $C$ and $S$ treatments had access to an abundance of high quality forage. The $\mathbf{S}$ treatment steers were stocked at higher levels but for short periods of time. Allison and Kothmann (1979) reported that at lower stocking levels animals have increased selectivity as evidenced by an increase in in vitro digestibility of organic matter and crude protein of cattle diets. However, this appears not to have been a problem as steers on the $S$ treatment tended to select higher quality forage parts throughout the grazing season. Although greater acreage and sclectivity with treatment may have been responsible for increased gains, the lower

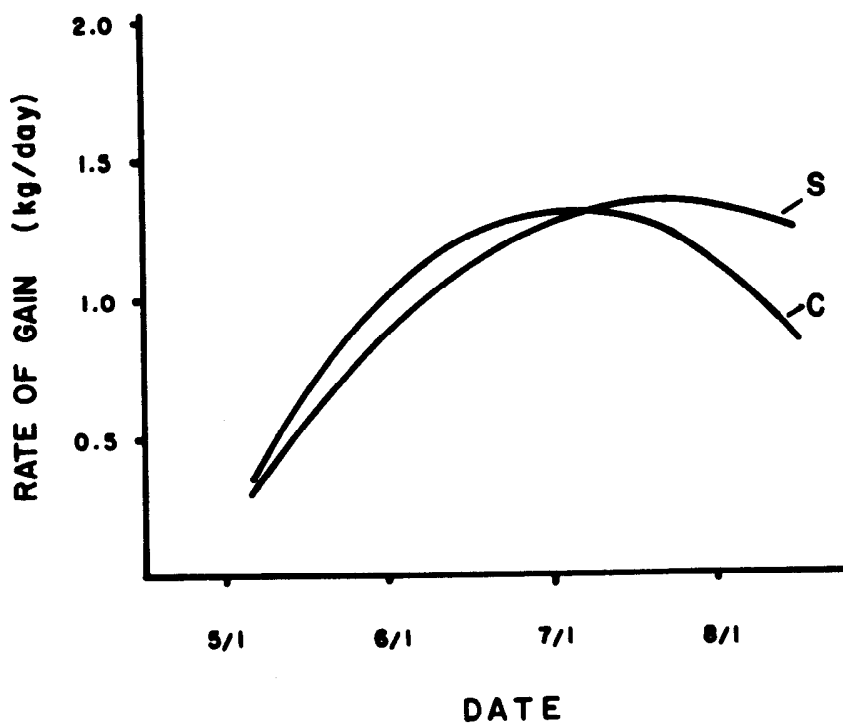

Fig. 6. Steer rate of gain ( $\mathrm{kg} / \mathrm{ha})$ curves for the continuous (C) and short duration (S) grazing treatments in Trial 2.

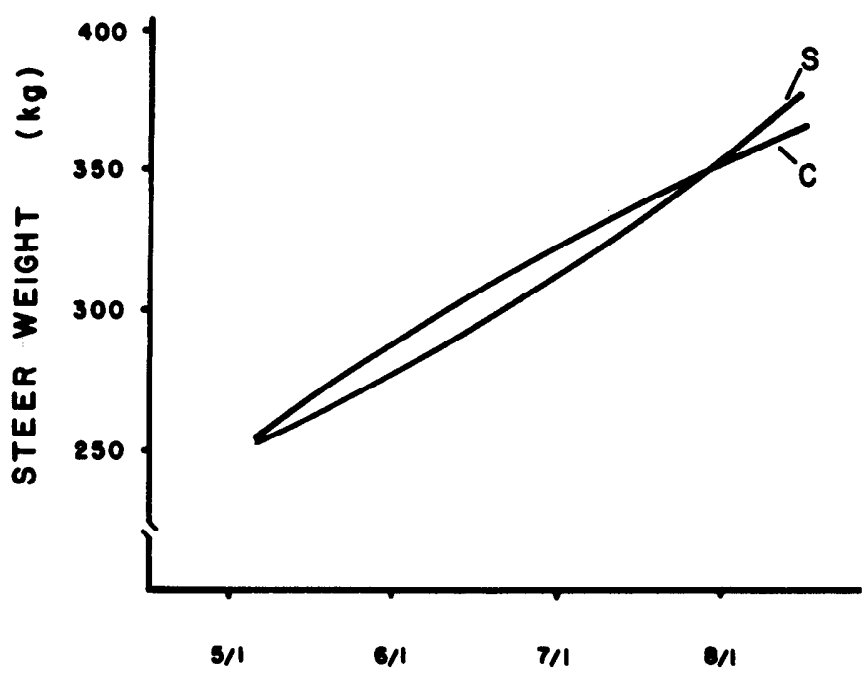

\section{DATE}

Fig. 7. Steer growth curves for the continuous (C) and short duration (S) grazing treatments in Trial 2.

gains on treatment $S$ were probably the result of increased animal movements early in the season. The $S$ treatment fields, used early in the season, were small ( 6.5 to $9.0 \mathrm{ha})$ and the movements were frequent ( 8 to 16 days). The movements were usually early in the morning, a peak grazing time, and steers would habitually walk a new field, further reducing grazing time and expending energy with increased activity.

Results indicated that the $\mathrm{S}$ treatment response came after forage had matured and nutritive value was declining. Further research is needed to define better what appears to be a potentially promising grazing practice. Intake studies, digestion trials, and long-term forage measurements would answer questions on the degree of increased selectivity afforded animals and the effects of the grazing treatment of forage production. Altering the grazing scheme so that a larger field could be grazed through mid-June and then starting short duration grazing of fields to increase the animals' selectivity could possibly increase animal performance. Additional advantages would be a reduction in frequency of animal movements and the omission of the need for follow-up grazing to stimulate tillering and reduce reproductive shoots. However, a planned pasture rotation system should be developed so that the same fields would not always be grazed in the spring. This would result in a deferred rotational system including short duration grazing from mid-June to mid-August.

\section{Literature Cited}

Allison, C.D. and M.M Kothmann. 1979. Effect of level of stocking pressure on forage intake and diet quality of range cattle. Proc. West. Sec. Amer. Soc. Anim. Sci. 30:174-178.

Hyder, D.N., and Forrest A. Sneva. 1963. Morphological and physiological factors affecting the grazing management of crested wheatgrass. Crop Sci. 3:267-271.

Raleigh, R.J. 1970. Symposium on pasture methods for maximum production in beef cattle: manipulation of both livestock and forage management to give optimum production. J. Anim. Sci. 30:108-114.

Sharp, Lee A. 1970. Suggested management programs for grazing crested wheatgrass. Forest, Wildlife and Range Exp. Sta. Univ. of Idaho. Bull. \#4. 19 p.

Snedecor, G., and W.G. Cochran. 1972. Statistical methods (7th Ed.) Iowa State Univ. Press, Ames.

Sneva, F.A. 1979. Unpublished file data. Squaw Butte Station. Oregon State Univ. Burns.

Steel, R.G.D., and J.H. Torrie. 1960. Principles and procedures of statistics. McGraw-Hill Book Co., New York.

Van Poollen, Walt H., and John R. Lacey. 1979. Herbage response to grazing systems and stocking intensities. J. Range Manage. 32:250-253. 